\title{
PENGEMBANGAN SSP TEMATIK-INTEGRATIF UNTUK MEMBANGUN KARAKTER DISIPLIN DAN KREATIF SISWA KELAS I SD
}

\section{DEVELOPING THEMATIC-INTEGRATED SSP FOR BUILDING THE CHARACTERS OF DISCIPLINE AND CREATIVE OF GRADE I STUDENT ELEMENTARY SCHOOL}

\author{
Wawan Wahyu Setyawan, Ali Mustadi \\ SD Baran Bantul Yogyakarta, Universitas Negeri Yogyakarta \\ wawan_ws79@yahool.com, aly_uny@yahoo.com
}

\begin{abstract}
Abstrak
Penelitian ini bertujuan untuk menghasilkan perangkat pembelajaran terpadu berupa Subject Spesific Pedagogy (SSP) Tematik-Integratif yang dapat membangun karakter siswa kelas I sekolah dasar, terutama karakter disiplin dan kreatif. Penelitian ini merupakan penelitian dan pengembangan yang terdiri dari sepuluh tahap, yaitu penelitian dan pengumpulan data, perencanaan, pengembangan draft produk, uji coba lapangan awal, revisi hasil uji coba, uji coba lapangan, revisi produk hasil uji coba lapangan, uji pelaksanaan lapangan, penyempurnaan produk akhir, dan diseminasi produk. SSP yang dikembangkan dievaluasi oleh ahli materi dan media untuk mengetahui kelayakannya. Subjek uji coba berjumlah 82 siswa terdiri dari 26 siswa SD Baran, Pundong, Bantul, DIY sebagai subjek uji coba terbatas, 25 siswa SD Manding Tengah untuk kelas kontrol, dan 31 siswa SD Tulung, Pundong, Bantul, DIY untuk kelas eksperimen. Hasil penelitian ini berupa produk SSP yang meliputi: silabus, RPP, bahan ajar, LKS, dan instrumen penilaian. Hasil penilaian menunjukkan bahwa produk SSP dinyatakan layak dengan perincian silabus berkategori baik dengan skor 47, RPP skor 67, bahan ajar skor 65, LKPD skor 47 dan instrumen penilaian yang dikembangkan dinyatakan valid berkategori sangat baik, sedangkan media pembelajaran yang dikembangkan berkategori baik dengan skor 66. Hasil uji coba menunjukkan bahwa SSP yang dikembangkan dinyatakan memenuhi kriteria praktis dilihat dari penilaian guru skor 281 dan respon siswa skor 730. Pada uji coba lapangan didapatkan hasil untuk kelas kontrol rata-rata skor pretest 70,8 dan rata-rata skor posttest 80,8.Sedangkan pada kelas eksperimen memperoleh skor rata-rata pretest 74,1 dan skor posttest 90,9. Peningkatan skor kelas kontrol sebesar 10 dan peningkatan kelas eksperimen sebesar 16,8. Pembelajaran dengan SSP yang dikembangkan mampu membangun karakter disiplin dan kreatif. Rata-rata hasil penilaian afektif siswa untuk karakter disiplin adalah $100 \%$ dan kreatif adalah $94 \%$.
\end{abstract}

Kata Kunci: SSP, karakter, disiplin, kreatif

\section{Abstract}

This study aims to produce integrated learning sets in the form of thematic SSP that can develop the characters of discipline and creative of grade I students of elementary school.This was a research and development study consisting of seven steps, namely: preliminary study and data collection, planning, product draft development, preliminary field tryout, revision of the tryout result, field tryout, product finalization based the field tryout result, field implementation testing, final product finalization, and dissemination. The developed SSP was evaluated by a science subject expert to assess the validity. The tryout subjects comprised 82 students consisting of 26 students of SD Baran, Pundong, Bantul, DIY in the small-scale tryout, 25 students in the control class of SD Manding Tengah, Bantul, DIY and 31 students in the experimental class of SD 1 Tulung, Bantul, DIY. The results of this study are in the form of SSP consisting of: a syllabus, lesson plans, course sheets, student worksheets, and evaluation sheets. The results of the evaluation show that the developed syllabus is good score of 47. The developed lesson plans score of 67, student course sheets score of 65, student worksheets score of 47, and assessment instruments, are very good, while the developed learning media are good score of 66. The results of the tryout show that the developed SSP otherwise meet the criteria for the practical views of teacher assessment score of 281 and a score of 730 student responses. In field trials the results obtained for the control class average pretest score of 70.8 and an average posttest score of 80.8. While the experimental class scored an average of 74.1 pretest and posttest score of 90.9. Improved control class scores of 10 and an increase of 16.8 experimental class. Teaching using developed SSP is capable of developing students' characters in discipline and creativity. Average of the students' affective learning achievement in the character of discipline is $100 \%$ and creativity $94 \%$.

Keywords: SSP, characters, discipline, creative 


\section{Pendahuluan}

Pendidikan karakter bangsa merupakan salah satu kebutuhan penting dalam kehidupan berbangsa dan bernegara. Pemerintah melalui Kementerian Pendidikan dan Kebudayaan sangat gencar melakukan berbagai kajian untuk mendapatkan rumusan terbaik dalam penerapan nilai-nilai karakter kepada peserta didik. Beberapa kasus kriminal yang melibatkan anak sekolah seperti tawuran, penggunaan narkoba, bullying dan mencontek dalam ujian menjadi bukti betapa pentingnya pendidikan karakter sejak dini.

Pendidikan karakter sebaiknya dilakukan sejak dini. Perwujudannya melalui pendidikan yang paling dasar yaitu sekolah dasar. Sekolah dasar mempunyai peran strategis dalam menanam dan mengembangkan karakter kepada peserta didik. Dalam artikelnya Johnson (2010, p.1) menuliskan bahwa "Character education in schools is where most children will probably develop their character". Pernyataan Bob Johnson tersebut menjelaskan bahwa pendidikan karakter di sekolah merupakan tempat yang memiliki peluang mengembangkan karakter anak. Implementasinya dengan memasukan pendidikan karakter ke dalam kurikulum sekolah dasar.

Penanaman konsep yang paling awal pada pendidikan di sekolah dasar terjadi pada kelas I, II, dan III yang biasa disebut dengan kelas rendah. Berdasarkan teori perkembangan kognitif Piaget (Shaffer and Kipp, 2007, p. 55) pada usia tersebut peserta didik berada pada tahap concrete operations (operasional konkret) dimana peserta didik mendapatkan dan menggunakan segala pengetahuannya dengan sesuatu yang logis atau masuk akal. Hal yang logis tersebut bisa didapatkan melalui kegiatan-kegiatan konkret dan bermakna. Oleh karena itu, dibutuhkan cara penanaman konsep yang baik untuk peserta didik kelas rendah tersebut.

Jika berbicara mengenai konsep disebuah kelas, maka tidak akan lepas dari peran sebuah model pembelajaran. Berdasarkan karakteristik peserta didik kelas rendah tersebut, model pembelajaran yang tepat adalah tematik. Tematik merupakan sebuah pembelajaran yang menginspirasi dari teori psikologi Gestalt, dimana siswa kelas rendah sekolah dasar masih memandang segala sesuatu sebagai sebuah kesatuan yang utuh dan saling terkait atau sering disebut holistik.
Pembelajaran tematik di sekolah dasar merupakan terapan dari pembelajaran terpadu yaitu dengan mengintegrasikan beberapa aspek, baik dalam mata pelajaran maupun antar mata pelajaran. Dengan adanya pemaduan tersebut, peserta didik memperoleh pengetahuan dan keterampilan secara utuh sehingga pembelajaran menjadi lebih bermakna bagi peserta didik (Sukayati, 2004, p.2)

Dari pengamatan terhadap peserta didik diperoleh gambaran bahwa karakter yang mendesak perlu dibangun adalah karakter disiplin dan kreatif. Data selama pengamatan di sekolah menunjukkan, bahwa mereka selama di sekolah memiliki disiplin yang rendah. Hal ini terlihat dari beberapa indikator yang menunjukkan keadaan tersebut. Berdasarkan peraturan sekolah pada pukul 07.00 WIB waktu bel masuk berbunyi peserta didik seharusnya sudah berada di sekolahan dan siap masuk ke kelas. Tetapi kenyataan menunjukkan bahwa setelah bel berbunyi ternyata ada beberapa peserta didik yang terlambat masuk ke kelas. Ketika masuk ke kelas, peserta didik juga tidak antri dan saling mendahului hal ini menimbulkan kegaduhan dan berimbas pada pelaksananan berdoa menjadi kurang khidmat. Kagaduhan juga berulang ketika peserta didik pulang sekolah. Mereka keluar dengan suara gaduh dan tidak tertib.

Selama proses pembelajaran ketidakdisiplinan peserta didik juga terlihat. Beberapa peserta didik tidak menyiapkan peralatan sekolah yang diperlukan untuk pelajaran hari itu. Sedangkan peserta didik yang lain menyiapkan perlatan sekolah tetapi tidak rapi dan asal bawa. Indikator lain yang ditemukan, peserta didik dalam mengerjakan tugas tidak tepat waktu sesuai dengan petunjuk dan perintah guru. Sehingga pelaksanaan pengumpulan tugas menjadi tidak tertib.

Masalah disiplin peserta didik juga ditemukan juga dalam hal menjaga kebersihan lingkungan. Di sekolah sudah disediakan 3 jenis tempat sampah yang berbeda yaitu tempat sampah untuk jenis benda-benda organik, anorganik dan sampah yang berwujud cairan. Meskipun sudah disediakan 3 jenis tempat sampah yang berbeda ternyata masih ditemukan adanya peserta didik yang tidak disiplin membuang sampah pada tempatnya. Mereka membuang sampah secara sembarangan tanpa memperhatikan jenis sampah yang dibuangnya. Hal ini mengakibatkan sampah menjadi bercampur satu dengan yang lain sehingga menyebabkan bau busuk. 
Di samping karakter disiplin yang perlu dikembangkan lain adalah karakter kreatif. Karakter kreatif siswa mununjukkan indikator yang rendah. Hal ini terlihat dalam proses pembelajaran. Ketika guru memberikan stimulan dengan menunjukkan suatu benda yang unik, siswa seakan tidak tertarik. Mereka tidak merespon baik ditunjukkan dengan ucapan maupun gerak-gerik. Hal ini juga terjadi ketika mereka mereka membuat prakarya berupa gambar. Mereka membuat karya yang sama dengan temannya baik dalam hal warna, bentuk maupun ukuran. Padahal guru sudah memberikan petunjuk dengan memberi kebebasan terhadap pemilihan warna, bentuk maupun ukuran. Hal ini juga terlihat dalam proses merancang dan membuat karya secara keseluruhan.

Berdasarkan hal tersebut, peneliti mengembangkan SSP tematik yang terintegrasi dengan karakter peserta didik khususnya karakter disiplin dan karakter yang mengakomodasi karakter kreatif dalam pembelajarannya. Dengan demikian, diharapkan karakter disiplin dan kreatif siswa dapat terbangun melalui penggunaan SSP ini. Penelitian pengembangan ini bertujuan untuk menghasilkan dan mengetahui efektivitas SSP tematik untuk membangun karakter disiplin dan kreatif peserta didik kelas I Sekolah Dasar Negeri Baran Kecamatan Pundong.

Produk yang dihasilkan dalam penelitian pengembangan ini adalah perangkat pembelajaran Subject Spesific Pedagogy (SSP) pelajaran tematik-integratif untuk membangun karakter peserta didik kelas I Sekolah Dasar Negeri Baran Kecamatan Pundong. Adapun spesifikasi perangkat pembelajaran yang dikembangkan adalah penyusunan secara terpadu perangkat pembelajaran SSP pelajaran tematik yang didahului dengan analisis tugas. Perangkat pembelajaran yang dimaksud yaitu berupa silabus, Rencana Pelaksanaan Pembelajaran (RPP), bahan ajar, Lembar Kerja Peserta Didik (LKPD), dan lembar penilaian dalam bentuk media cetak sebagai panduan guru untuk melaksanakan kegiatan pembelajaran.

\section{Metode}

Jenis Penelitian

Penelitian ini menggunakan jenis penelitian Research and Development (R \& D). Prosedur pengembangan diadaptasi dari model pengembangan menurut Borg \& Gall (1983, p.775).
Adapun pengembangan produk dimulai pada bulan Juni Tahun 2013 dan dilanjutkan dengan uji coba produk dilakukan pada bulan Maret 2014. Proses penelitian ini dilakukan dengan melakukan 10 langkah penelitian seperti yang ditunjukan oleh Borg \& Gall. Kesepuluh langkah tersebut yaitu: (1) research and information, (2) planning, (3) develop preliminary form of product, (4) preliminary field testing, (5) main product revision, (6) main field testing, (7) operational product testing, (8) operational field testing, (9) final product revision, dan (10) dessimination and implementation.

Langkah-langkah penelitian di kelompokkan menjadi empat tahap yaitu: (1) eksplorasi, (2) rancangan pengembangan, (3) uji lapangan, dan (4) finalisasi. Tahap eksplorasi meliputi analisis kebutuhan (Need Analysis), analisis literatur dan analisis dokumen perangkat pembelajaran. Rancangan pengembangan meliputi pemilihan format, penentuan perangkat pembelajaran, perancangan $S S P$, validasi ahli, analisis data validasi ahli. uji lapangan meliputi uji coba terbatas, analisis uji coba terbatas, uji coba lapangan, analisis uji coba lapangan. Finalisasi meliputi implementasi dan diseminasi.

\section{Uji Coba Produk}

Uji coba yang dilakukan terdiri dari dua tahap, yaitu uji coba terbatas dan uji coba lapangan. Pada uji coba terbatas dilakukan dengan menggunakan desain one-shot case study seperti pada gambar 3. Penilaian pada uji coba terbatas menggunakan nilai posttest.

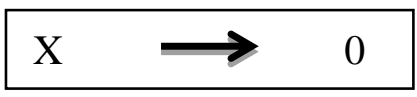

Gambar 1. Desain one-shot case study

Keterangan:

$\mathrm{X}=$ Treatment (perlakuan), penggunaan SSP dalam pembelajaran

$\mathrm{O}=$ Pengamatan/hasil uji coba terbatas

Sedangkan, uji coba lapangan terhadap pengembangan SSP tematik dalam mengembangkan karakter peserta didik dilakukan dengan menggunakan metode eksperimen yang terdiri dari kelas kontrol dan kelas eksperimen. Uji coba lapangan menggunakan desain pretestposttest control group. Desain uji coba dapat dilihat pada tabel 1 . 
Tabel 1. Desain Pretest-Posttest Control Group

\begin{tabular}{cccc}
\hline Kelompok & Pretest & Perlakuan & Posttest \\
\hline Kontrol (KK) & T1 & X- & T2 \\
Eksperimen (KE) & T1 & Xa & T2 \\
\hline
\end{tabular}

Keterangan

$\mathrm{T} 1$ = Kemampuan awal

$\mathrm{T} 2=$ Tes hasil belajar dan penilaian karakter

$\mathrm{X}$ - = Pembelajaran tematik menggunakan perangkat dari guru kelas awal

$\mathrm{Xa}=$ Pembelajaran tematik menggunakan SSP.

Subjek Uji Coba

Subjek uji coba terbatas adalah satu orang guru mitra dan peserta didik kelas I SD N Baran. Sedangkan subjek penelitian uji coba lapangan adalah peserta didik kelas I SD Manding Tengah, Bantul, Yogyakarta sebagai Kelas Kontrol (KK), satu orang guru mitra dan peserta didik kelas I SD Tulung, Pundong Bantul, Yogyakarta sebagai Kelas Eksperimen (KE).

Jenis Data

Data penelitian ini berupa data validasi ahli mengenai kelayakan produk yang dikembangkan berupa $S S P$, angket penilaian guru terhadap SSP yang dikembangkan, angket respon siswa, data hasil pengamatan perilaku karakter dan angket pengamatan orang tua peserta didik.

\section{Teknik Pengumpulan Data}

Teknik pengumpulan data yang digunakan adalah: wawancara, penilaian produk oleh ahli, observasi, tes, angket

Instrumen Pengumpulan Data

Instrumen pengumpulan data yang digunakan adalah: pedoman wawancara, lembar penilaian produk, lembar pengamatan, soal, lembar angket

\section{Teknik Analis Data}

Penelitian ini data dianalisa untuk mendapatkan perangkat pembelajaran berupa $S S P$ yang layak dan efektif. Apabila kedua syarat ini terpenuhi, produk SSP yang dikembangkan layak untuk digunakan. Adapun langkah-langkah yang dilakukan untuk memenuhi kedua kriteria terhadap produk SSP yang dikembangkan adalah: (a) Data berupa skor dari para ahli diperoleh melalui lembar validasi. (b) Total skor aktual yang diperoleh kemudian dikonversikan menjadi data kuantitatif skala lima.

Menurut Sukardjo (2005, p.55) skor yang diperoleh kemudian dikonversikan menjadi ni- lai pada skala 5, dengan acuan tabel sebagai berikut:

Tabel 2. Konversi Skor Aktual Menjadi Skor Skala Lima Berdasarkan Simpangan Baku (SB)

\begin{tabular}{|c|c|c|}
\hline Interval Skor & Nilai & Kategori \\
\hline $\mathrm{X}>\mathrm{Mi}+1,8 \mathrm{Sbi}$ & $\mathrm{A}$ & Sangat baik \\
\hline $\begin{array}{c}\mathrm{Mi}+0,6 \mathrm{SBi}<\mathrm{X} \leq \mathrm{Mi}+1,8 \\
\text { Sbi }\end{array}$ & B & Baik \\
\hline $\begin{array}{c}\mathrm{Mi}-0,6 \mathrm{SBi}<\mathrm{X} \leq \mathrm{Mi}+0,6 \\
\mathrm{Sbi}\end{array}$ & $\mathrm{C}$ & Cukup baik \\
\hline $\begin{array}{c}\mathrm{Mi}-1,8 \mathrm{SBi}<\mathrm{X} \leq \mathrm{Mi}-0,6 \\
\text { Sbi }\end{array}$ & D & Kurang baik \\
\hline $\mathrm{X} \leq \mathrm{Mi}-1,8 \mathrm{Sbi}$ & $\mathrm{E}$ & $\begin{array}{c}\text { Sangat } \\
\text { kurang baik }\end{array}$ \\
\hline
\end{tabular}

Keterangan:

$\mathrm{X}=$ skor aktual (empiris)

$\mathrm{Mi}=$ mean ideal, dihitung dengan menggunakan rumus :

$\mathrm{Mi}=1 / 2($ skor maksimal ideal + skor minimal ideal)

$\mathrm{SBi}=$ simpangan baku ideal, ditentukan dengan rumus:

$\mathrm{SBi}=1 / 6$ (skor maksimal ideal - skor minimal ideal

Skala 5 tersebut diketahui bahwa skor maksimal ideal $=5$ dan skor minimal ideal $=1$, sehingga diperoleh perhitungan mi dan SBi sbb:

$\mathrm{Mi}=1 / 2(5+1)=3$

$\mathrm{Sbi}=1 / 6(5-1)=0,67$

\section{Hasil dan Pembahasan}

Hasil Pengembangan pada deskrepsi awal yang pertama melakukan analisis kebutuhan (Need Analysis). Analisis kebutuhan dilakukan untuk mendapatkan informasi yang akurat tentang kebutuhan siswa dan guru. Berdasarkan hasil pengamatan pembelajaran di kelas dan wawancara guru maka perlu dikembangkan perangkat pembelajaran berupa $S S P$ yang sesuai dengan karakteristik siswa. SSP yang dikembangkan diharapkan dapat digunakan untuk melatih siswa dalam membangun karakter peserta didik terutama karakter disiplin dan kreatif. Tema pembelajaran yang dipandang sesuai adalah tema "Benda, hewan dan tanaman di sekitarku" sub tema "Benda hidup dan benda tak hidup di sekitarku" dan pembelajarannya dilaksanakan semester II pada bulan Maret 2014. Proses yang kedua adalah analisis literatur. Analisis literatur dengan mengkaji kurikulum, materi, jenis perangkat SSP, metode, dan tujuan pembelajaran.

Tahap perancangan (Design) terdiri dari tiga langkah yaitu pemilihan format, penentuan perangkat pembelajaran dan perancangan SSP. 
Format pengembangan karakter yang dipilih adalah mengintegrasikan nilai-nilai karakter ke dalam materi pelajaran. Penentuan perangkat pembelajaran dipilih perangkat pembelajaran yang terintegrasi dengan pengembangan karakter siswa. Adapun perangkat pembelajaran yang dikembangkan adalah silabus, RPP, bahan ajar, LKPD, dan instrumen penelitian. SSP yang dirancang untuk penelitian pengembangan meliputi: Silabus, RPP, Bahan Ajar, LKPD, Instrumen Penilaian.

Produk awal SSP yang sudah dirancang kemudian dievaluasi oleh ahli mata pelajaran dan ahli media. Data yang diperoleh dalam penelitian pengembangan ini merupakan data hasil evaluasi kevalidan, kepraktisan, dan keefektifan produk yang dilakukan oleh ahli pembelajaran dan ahli media.

Tabel 3. Data Hasil Penilaian Kevalidan SSP oleh Ahli Pembelajaran

\begin{tabular}{clcc}
\hline No & $\begin{array}{c}\text { Komponen } \\
\text { SSP }\end{array}$ & $\begin{array}{c}\text { Total Skor } \\
\text { Aktual }(\mathbf{X})\end{array}$ & $\begin{array}{c}\text { Kategori } \\
\text { Kevalidan }\end{array}$ \\
\hline 1 & Silabus & 47 & Baik \\
2 & RPP & 67 & Baik \\
3 & Bahan Ajar & 65 & Baik \\
4 & LKPD & 47 & Sangat Baik \\
5 & Lembar & Valid & Sangat Baik \\
& Penilaian & & \\
\hline
\end{tabular}

Ringkasan data hasil evaluasi kevalidan masing-masing dapat dilihat pada tabel 3, tabel 4 , tabel 5 dan tabel 6 .

Tabel 4. Data Hasil Penilaian Kevalidan SSP oleh Ahli Media Pembelajaran

\begin{tabular}{llcc}
\hline No & $\begin{array}{c}\text { Komponen } \\
\text { SSP }\end{array}$ & $\begin{array}{c}\text { Total Skor } \\
\text { Aktual (X) }\end{array}$ & $\begin{array}{c}\text { Kategori } \\
\text { Kelayakan }\end{array}$ \\
\hline 1 & Silabus & & \\
2 & RPP & & \\
3 & Bahan Ajar & 66 & Baik \\
4 & LKPD & & \\
5 & Lembar & & \\
& Penilaian & & \\
\hline
\end{tabular}

Data hasil penilaian kevalidan SSP oleh ahli Media Pembelajaran mendapat skor 66 dan dikategorikan baik
Tabel 5. Data Hasil Penilaian Kevalidan Instrumen Kepraktisan SSP oleh Ahli Pembelajaran

\begin{tabular}{|c|c|c|c|}
\hline No & $\begin{array}{c}\text { Komponen } \\
\text { SSP }\end{array}$ & $\begin{array}{c}\text { Penilaian } \\
\text { Kelayakan }\end{array}$ & $\begin{array}{c}\text { Kategori } \\
\text { Kevalidan }\end{array}$ \\
\hline 1 & $\begin{array}{l}\text { Lembar } \\
\text { penilaian guru }\end{array}$ & $\begin{array}{c}\text { Valid dengan } \\
\text { revisi }\end{array}$ & Baik \\
\hline 2 & $\begin{array}{l}\text { Lembar } \\
\text { pengamatan } \\
\text { respon peserta } \\
\text { didik }\end{array}$ & $\begin{array}{c}\text { Valid dengan } \\
\text { revisi }\end{array}$ & Baik \\
\hline
\end{tabular}

Data hasil penilaian kevalidan Instrumen kepraktisan SSP oleh ahli pembelajaran menunjukkan lembar penilaian guru dan lembar pengamatan respon peserta dinilai valid dengan revisi berkategori baik.

Tabel 6. Data Hasil Penilaian Kevalidan Instrumen Keefektifan SSP oleh Ahli Pembelajaran

\begin{tabular}{|c|c|c|c|}
\hline No & $\begin{array}{c}\text { Komponen } \\
\text { SSP }\end{array}$ & $\begin{array}{c}\text { Penilaian } \\
\text { Kelayakan }\end{array}$ & $\begin{array}{c}\text { Kategori } \\
\text { Kevalidan }\end{array}$ \\
\hline 1 & $\begin{array}{l}\text { Lembar } \\
\text { Pengamatan } \\
\text { Karakter }\end{array}$ & $\begin{array}{l}\text { Valid dengan } \\
\text { revisi }\end{array}$ & Baik \\
\hline 2 & $\begin{array}{l}\text { Lembar } \\
\text { penilaian } \\
\text { karakter }\end{array}$ & $\begin{array}{c}\text { Valid dengan } \\
\text { revisi }\end{array}$ & Baik \\
\hline
\end{tabular}

Uji coba terbatas dilakukan untuk memperoleh data terkait SSP yang dikembangkan.

Pengukuran tingkat kepraktisan SSP dilakukan dengan cara pengisian angket penilaian guru terhadap SSP dan angket respon peserta didik terhadap proses pembelajaran. Sedangkan pengukuran keefektifan SSP dilakukan dengan pengisian lembar pengamatan karakter peserta didik oleh pengamat dan angket penilaian karakter peserta didik. Selain itu, pengukuran SSP juga dilakukan dengan penilaian terhadap hasil posttest peserta didik.

Ringkasan data hasil penilaian guru terhadap SSP yang dikembangkan dan hasil pengamatan respon peserta didik terhadap SSP yang dikembangkan dapat dilihat pada tabel 7.

Tabel 7. Data Hasil Penilaian Kepraktisan SSP pada Uji Coba terbatas

\begin{tabular}{clcc}
\hline No & $\begin{array}{c}\text { Komponen } \\
\text { Kepraktisan SSP }\end{array}$ & $\begin{array}{c}\text { Rerata } \\
\text { Total Skor } \\
\text { Aktual }\end{array}$ & $\begin{array}{c}\text { Kategori } \\
\text { Kepraktisan }\end{array}$ \\
\hline 1 & $\begin{array}{l}\text { Angket Penilaian } \\
\text { Guru }\end{array}$ & 280 & Sangat Baik \\
2 & Respon Siswa & 775 & Sangat Baik \\
\hline
\end{tabular}

Pengukuran keefektifan SSP tematik dalam mengembangkan karakter peserta didik 
kelas I SD selama proses pembelajaran dilakukan dengan pengisian lembar pengamatan karakter peserta didik oleh pengamat, pengisian penilaian karakter peserta didik dan penilaian terhadap hasil posttest peserta didik. Ringkasan data hasil pengukuran keefektifan SSP berupa pengisian lembar pengamatan karakter peserta didik dan hasil penilaian karakter dapat dilihat pada tabel 8 .

Tabel 8. Data Hasil penilaian Keefektifan SSP pada Uji Coba Terbatas

\begin{tabular}{clcl}
\hline No & $\begin{array}{c}\text { Komponen } \\
\text { Keefektifan } \\
\text { SSP }\end{array}$ & $\begin{array}{c}\text { Rerata } \\
\text { Total Skor } \\
\text { Aktual (X) }\end{array}$ & $\begin{array}{c}\text { Kategori } \\
\text { Keefektifan }\end{array}$ \\
\hline 1 & $\begin{array}{l}\text { Lembar } \\
\text { Pengamatan }\end{array}$ & & \\
& Karakter & & \\
& Disiplin & 39,6 & Sangat baik \\
& Kreatif & 19,3 & Sangat baik \\
2 & Penilaian & 78,1 & Sangat baik \\
& karakter peserta \\
didik & & \\
\hline
\end{tabular}

\section{Data Uji Coba Lapangan}

SSP yang telah direvisi kemudian diujicobakan pada uji coba lapangan. Uji coba ini menggunakan metode eksperimen dengan desain Pretest-Postest Control Group.

Ringkasan data hasil pengukuran kepraktisan SSP dapat dilihat pada tabel 9.

Tabel 9. Data Hasil penilaian Kepraktisan SSP pada Uji Coba Lapangan

\begin{tabular}{clcc}
\hline No & $\begin{array}{l}\text { Komponen } \\
\text { Penilaian }\end{array}$ & $\begin{array}{c}\text { Rerata } \\
\text { Total Skor } \\
\text { Aktual }(\mathbf{X})\end{array}$ & $\begin{array}{c}\text { Kategori } \\
\text { Kepraktisan }\end{array}$ \\
\hline 1 & $\begin{array}{l}\text { Penilaian } \\
\text { guru }\end{array}$ & 281 & Sangat Baik \\
2 & $\begin{array}{l}\text { Respon } \\
\text { peserta didik }\end{array}$ & 730 & Baik \\
\hline
\end{tabular}

Ringkasan hasil pengukuran keefektifan SSP dapat dilihat pada tabel 10.

Tabel 10. Data Hasil Penilaian Keefektifan SSP pada Uji Coba Lapangan

\begin{tabular}{clcccc}
\hline \multirow{2}{*}{ No } & \multirow{2}{*}{ Komponen Penilaian } & \multicolumn{2}{c}{ Rerata Total Skor Aktual } & \multicolumn{2}{c}{ Kategori Keefektifan } \\
\cline { 3 - 6 } & & KK & KE & KK & KE \\
\hline 1 & Lembar Observasi peserta didik & & & & \\
& Disiplin & 33,3 & 35,3 & Baik & Baik \\
& Kreatif & 16,1 & 17,0 & Baik & Baik \\
2 & Penilaian Karakter peserta didik & 70,0 & 72,8 & Baik & Baik \\
\hline
\end{tabular}

Hasil analisis data penilaian karakter peserta didik yang telah dikonversi menjadi nilai skala lima dapat dilihat pada gambar 2 .

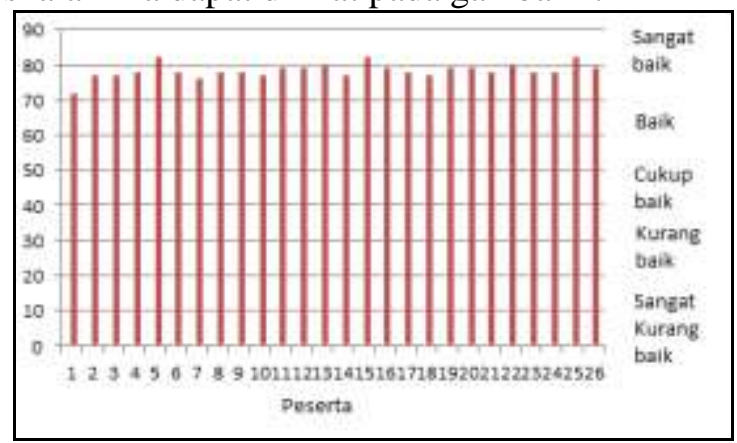

Gambar 2. Diagram Hasil Penilaian Karakter Peserta Didik pada Uji Coba Terbatas

Berdasarkan gambar 2 selanjutnya dapat dideskripsikan hasil penilaian karakter peserta didik dalam bentuk diagram persentase seperti yang tersaji pada gambar 3 .

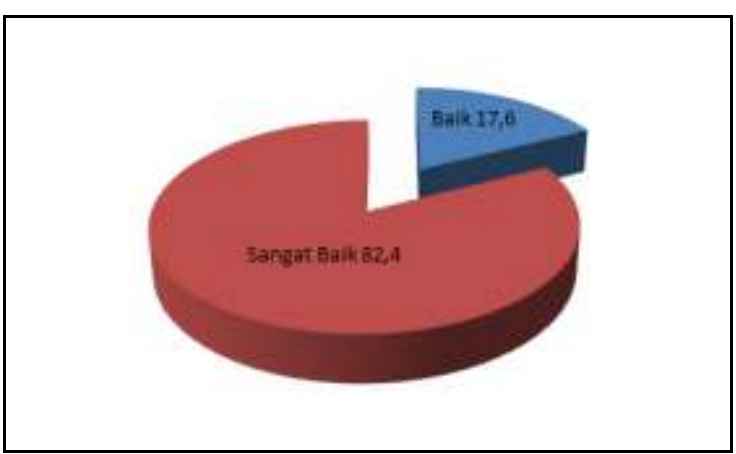

Gambar 3. Diagram Hasil Penilaian Karakter Peserta Didik pada Uji Coba Terbatas

Gambar 3 menunjukkan bahwa presentase orang tua peserta didik dalam menilai karakter pribadi anaknya berkategori "sangat baik" sebesar $17,6 \%$ dan berkategori "baik" sebesar $82,4 \%$. Artinya sebesar $17,2 \%$ dari jumlah subjek uji coba terbatas berkarakter "sangat baik" dan 82,4\% berkarakter "baik" setelah mengikuti pembelajaran menggunakan SSP. Hasil ini mengindikasikan bahwa SSP yang dikembangkan dapat dikatakan efektif karena lebih dari $80 \%$ peserta didik berkarakter "baik". 
Berdasarkan hasil analisis yang telah dilakukan menunjukkan bahwa hasil penilaian terhadap hasil belajar (posttest), pengamatan karakter, dan penilaian karakter peserta didik rata-rata berkategori "baik". Jumlah peserta didik yang memenuhi kategori "baik" pada masing-masing komponen juga lebih dari $80 \%$. Dengan demikian, dapat disimpulkan bahwa SSP yang dikembangkan dan diujikan pada uji coba terbatas efektif digunakan untuk membangun karakter peserta didik.

Uji coba lapangan dilakukan pada siswa kelas I SD Manding Tengah dan siswa kelas I SD Tulung Bantul. Siswa kelas I SD Manding Tengah yang berjumlah 25 peserta sebagai subjek Kelas Eksperimen (KE) dan 31 siswa kelas I SD Tulung dijadikan sebagai subjek Kelas Kontrol (KK). Pada uji coba lapangan KK melakukan pembelajaran dengan perangkat pembelajaran yang dibuat guru kelas sedangkan, KE melaksanakan pembelajaran menggunakan SSP. Adapun metode yang digunakan dalam uji coba lapangan adalah metode eksperimen dengan menggunakan desain pretest-posttest control group.

Kriteria kepraktisan SSP diperoleh dengan pengisian lembar penilaian guru terhadap SSP oleh guru kelas I dan pengisian angket respon siswa terhadap proses pembelajaran yang berlangsung oleh siswa kelas I. Hasil penilaian guru terhadap $S S P$ untuk masing-masing komponen $S S P$ dapat dilihat pada Gambar 4.

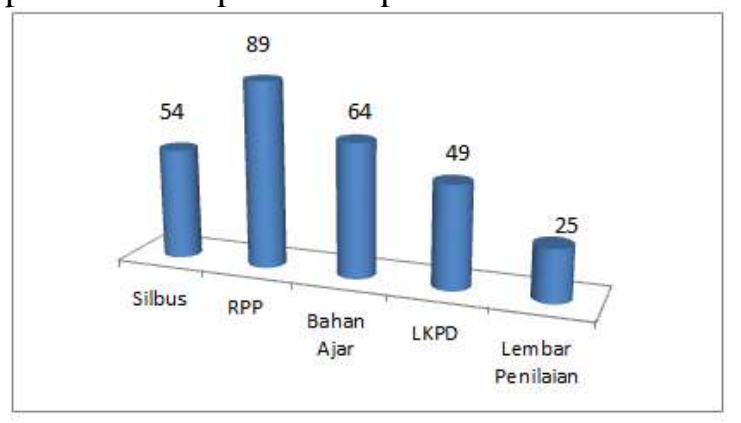

Gambar 4. Diagram Penilaian Guru terhadap Komponen SSP pada Uji Coba Lapangan

Seperti yang terlihat pada gambar 4 dapat diketahui total skor aktual penilaian guru terhadap SSP adalah 281. Total skor aktual kemudian dikonversi menjadi data skala lima. Berdasarkan hasil analisis, total skor aktual penilaian guru yang diperoleh pada uji coba lapangan ini berada pada interval berkategori "sangat baik". Hal ini mengindikasikan bahwa SSP dinilai praktis digunakan dalam pembelajaran.
Kriteria kepraktisan SSP juga dilihat dari tingkat respon siswa terhadap SSP melalui proses pembelajaran yang mereka alami. Data hasil respon siswa kemudian dianalisis dengan cara dikonversikan menjadi data skala lima. Hasil analisis respon siswa pada uji coba lapangan dapat dilihat pada Gambar 5.

Berdasarkan gambar 5, respon siswa terhadap SSP yang dikembangkan rata-rata berkategori "baik". Sebanyak 3 dari 31 siswa menyatakan bahwa SSP yang dikembangkan berkategori "sangat baik", 27 siswa menyatakan "baik" sementara 1 siswa menyatakan "cukup baik".

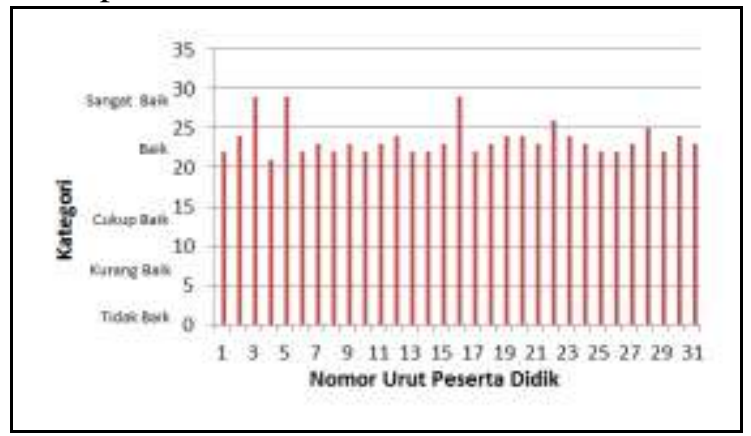

Gambar 5. Diagram Respon Peserta Didik terhadap SSP pada Uji Coba Lapangan

Sajian dalam bentuk diagram persentase perbandingan peserta didik yang merespon SSP berkategori "sangat baik", "baik" dan "cukup baik" dapat dilihat pada Gambar 6.

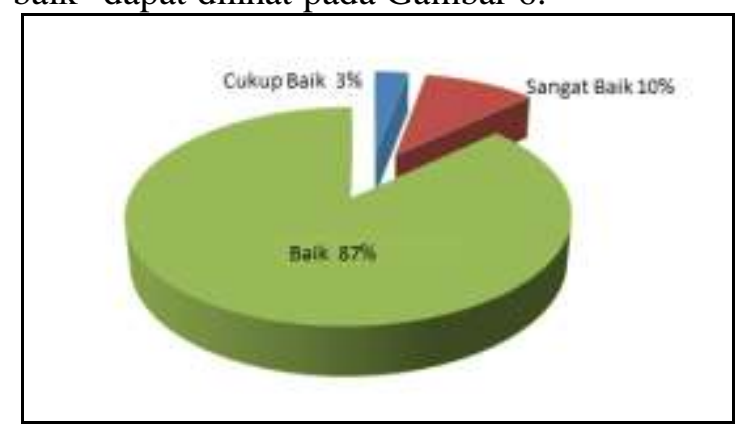

Gambar 6. Diagram Respon Peserta Didik terhadap SSP pada Uji Coba Lapangan

Gambar 6 memperlihatkan bahwa jumlah peserta didik yang merespon dengan kategori "sangat baik" sebesar 10\%, jumlah siswa yang merespon dengan kategori "baik" sebesar $87 \%$ dan jumlah siswa yang merespon dengan kategori "cukup baik" sebesar 3\%. Sementara itu hasil analisis rerata total skor aktual respon siswa yang dikonversikan menjadi data skala lima juga menyimpulkan bahwa SSP berada pada kategori "baik" yang mengindikasikan bahwa SSP dinilai praktis oleh siswa. 
Berdasarkan hasil analisis dari kedua komponen kepraktisan SSP menunjukkan bahwa SSP yang dikembangkan berkategori "baik". Selain itu jumlah siswa yang menilai SSP berkategori "baik" telah memenuhi syarat praktis yaitu lebih $80 \%$. Oleh karena itu, dapat disimpulkan bahwa SSP yang diukur melalui komponen penilaian guru dan respon siswa pada uji coba lapangan memenuhi kategori praktis.

Keefektifan SSP yang dikembangkan dilihat dari tes hasil belajar, hasil pengamatan karakter siswa, dan penilaian karakter siswa. Data tes hasil belajar siswa berupa pretest dan posttest Kelas Kontrol (KK) pada uji coba lapangan dapat dilihat pada Tabel 24 dan data pretest dan posttest Kelas Eksperimen (KE) dapat dilihat pada Tabel 25.

Data hasil pretest dan posttest pada KK dan KE pada uji coba lapangan akan dianalisa untuk mengetahui pengaruh penggunaan SSP dalam pembelajaran dan efektifitasnya. Analisis data untuk mengetahui pengaruh penggunaan SSP dilakukan dengan cara membandingkan rata-rata skor posttest dengan pretest KE terhadap rata-rata skor posttest dengan pretest $\mathrm{KK}$. Sedangkan analisa data untuk mengetahui tingkat efektifitas penggunaan SSP dalam pembelajaran dilakukan dengan membandingkan jumlah persentase siswa yang tuntas pada KE dengan KK. Hasil analisis data perbedaan skor rata-rata posttest dan pretest pada KE dan KK dapat dilihat pada tabel 11 .

Tabel 11. Data Hasil Analisis Rata-Rata Skor Posttest dan Pretest Kelas Kontrol dan Kelas Eksperimen pada Uji Coba Lapangan

\begin{tabular}{ccc}
\hline Perlakuan & \multicolumn{2}{c}{ Rata-Rata Skor } \\
\cline { 2 - 3 } & K.Kontrol & K.Eksperimen \\
\hline Pretest & 70,8 & 74,1 \\
Posttest & 80,8 & 90,9 \\
Beda & 10,0 & 16,8 \\
& \multicolumn{2}{c}{6,8} \\
\hline
\end{tabular}

Pada Tabel 11 terlihat bahwa terdapat perbedaan rata-rata skor pretest dan posttest antara KK dengan KE. Beda rata-rata skor posttest terhadap prestest pada KK adalah 10,0 poin sedangkan beda rata-rata skor posttest terhadap prestest pada $\mathrm{KE}$ adalah 16,8 poin. Hal ini mengindikasikan bahwa penggunaan SSP berpengaruh meningkatkan pemahaman siswa rata-rata yaitu sebesar 6,8 poin.

Selain untuk mengetahui pengaruh penggunaan SSP dalam pembelajaran, data skor pretest dan posttest peserta didik KK dan KE juga digunakan untuk mengetahui tingkat efektifitas penggunaan SSP dalam mengembangkan karakter siswa. Berdasarkan tabel 9 dapat dibuat diagram persentase siswa $\mathrm{KK}$ dan $\mathrm{KE}$ yang tuntas mengerjakan posttest seperti yang terlihat pada gambar 7 .
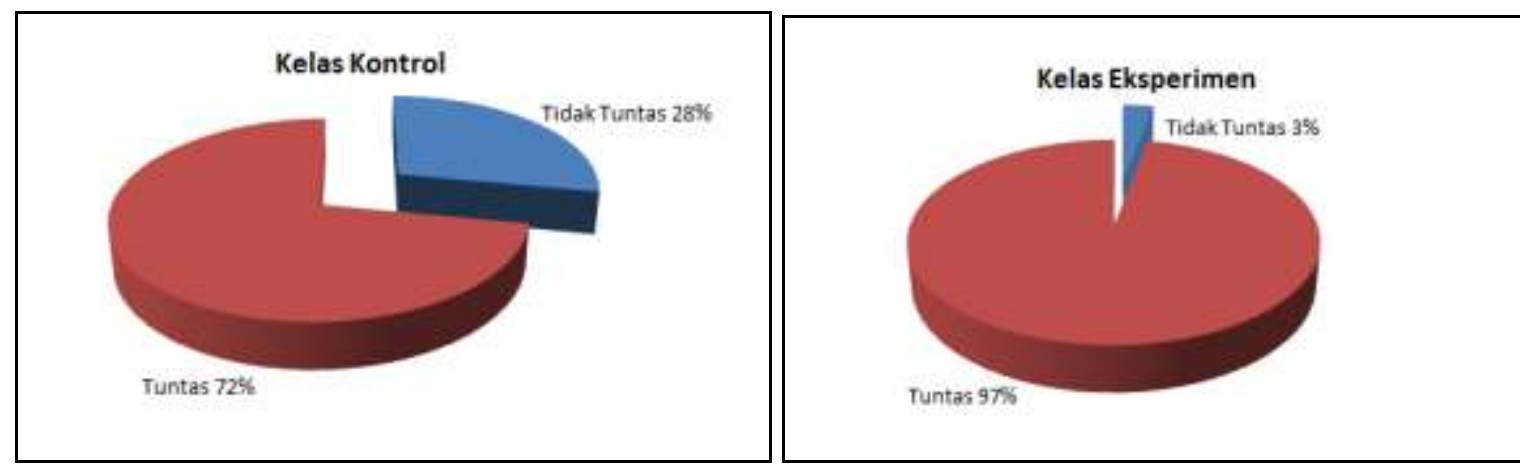

Gambar 7. Diagram Ketuntasan Hasil Belajar Akhir (Posttest) Peserta Didik pada Uji Coba Lapangan

Berdasarkan gambar 7 dapat diketahui bahwa pada KK persentase siswa yang tuntas sebesar $72 \%$ sementara persentase siswa yang tuntas pada KE sebesar 97\%. Hasil ini mengindikasikan dua penjelasan yakni (1) SSP yang digunakan terbukti efektif dilaksanakan karena lebih dari $80 \%$ siswa tuntas melaksanakan pembelajaran dan (2) SSP yang dikembangkan mampu meningkatkan pemahaman siswa akan materi pelajaran karena persentase siswa yang tuntas pada KE lebih besar dibandingkan dengan KK. Penjelasan kedua ini senada dengan hasil analisis sebelumnya yang menyimpulkan bahwa SSP berpengaruh dalam meningkatkan pemahaman siswa. Dari hasil analisis terhadap tes hasil belajar pada uji coba lapangan dapat diambil kesimpulan bahwa pada komponen tes hasil belajar SSP yang dikembangkan berkategori efektif sekaligus mempunyai pengaruh dalam meningkatkan pemahaman siswa. 
Komponen lain yang digunakan dalam mengukur tingkat efektifitas SSP adalah hasil pengamatan karakter siswa. Data hasil pengamatan tersebut dikonversikan menjadi data skala lima. Hasil analisis data pengamatan kedua jenis karakter peserta didik KK pada uji coba lapangan dapat dilihat masing-masing pada gambar 8 dan gambar 9 .

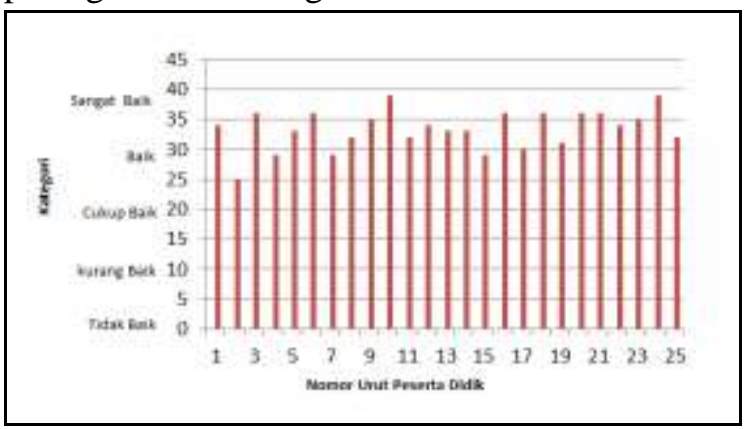

Gambar 8. Diagram Hasil Pengamatan Karakter Disiplin Kelas Kontrol pada Uji Coba Lapangan baik dan sisanya sebanyak 21 siswa berada dikategori baik.

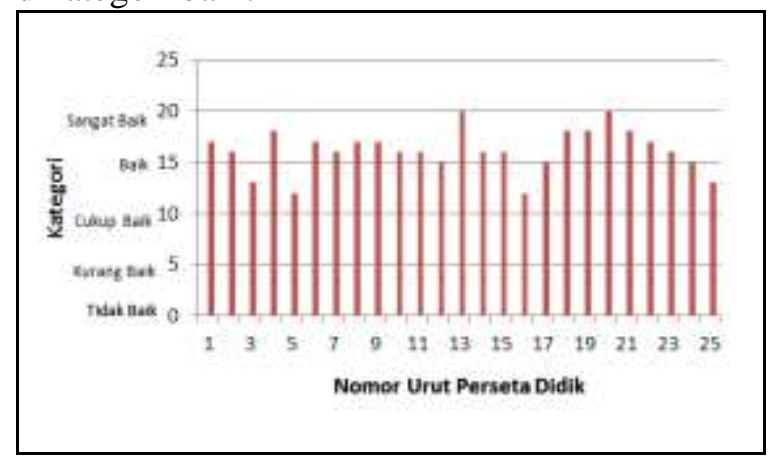

Gambar 9. Diagram Hasil Pengamatan Karakter Kreatif Kelas Kontrol pada Uji Coba Lapangan

Berdasarkan gambar 8 dan gambar 9 dapat dideskripsi hasil pengamatan siswa KK pada masing-masing karakter siswa ke dalam bentuk diagram persentase seperti yang tersaji pada Gambar 10.

Dari data gambar 9 telihat bahwa ada 4 peserta didik yang berada pad kategori cukup

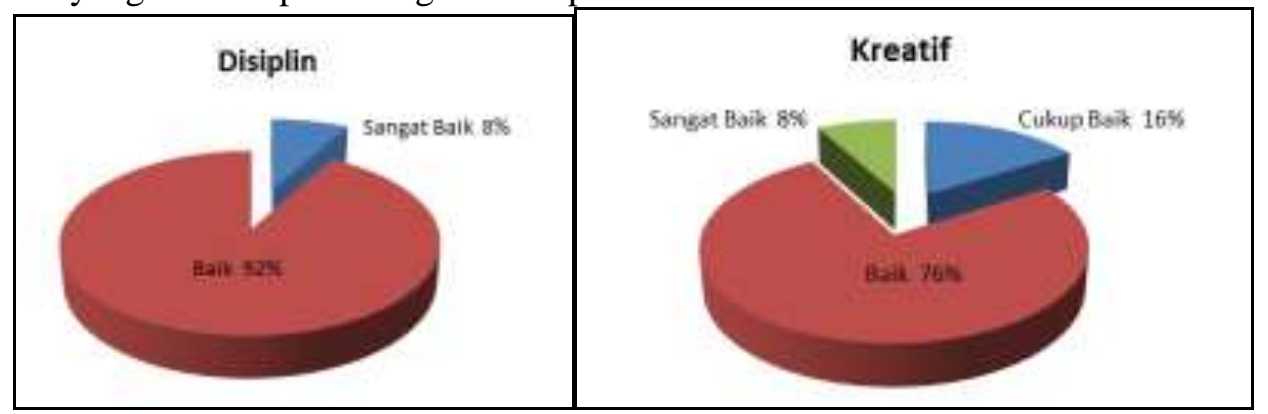

Gambar 10. Diagram Ketercapaian Karakter Peserta Didik Kelas Kontrol pada Uji Coba Lapangan

Gambar 10 menunjukan bahwa jumlah persentase siswa KK yang berkategori "baik" pada karakter disiplin sebesar $92 \%$. Sedangkan pada karakter kreatif sebesar $8 \%$ berkategori "sangat baik", 76\% berkategori "baik", $16 \%$ berkategori "cukup baik".

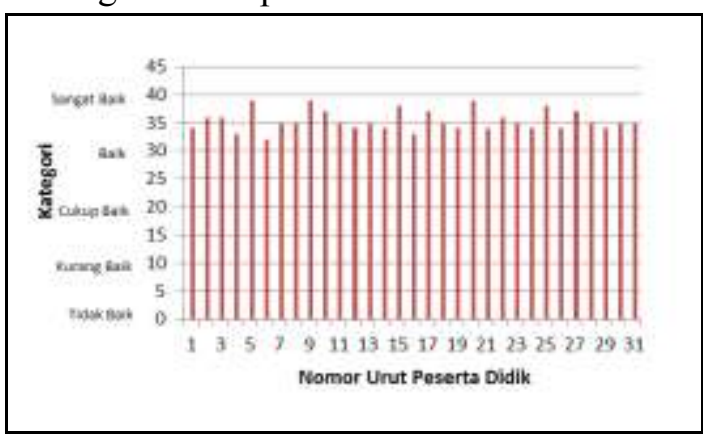

Gambar 11. Diagram Hasil Pengamatan Karakter Disiplin Kelas Eksperimen pada Uji Coba Lapangan

Sementara itu hasil analisis data pengamatan kedua jenis karakter siswa KE pada uji coba lapangan dapat dilihat masing-masing pada gambar 12 .

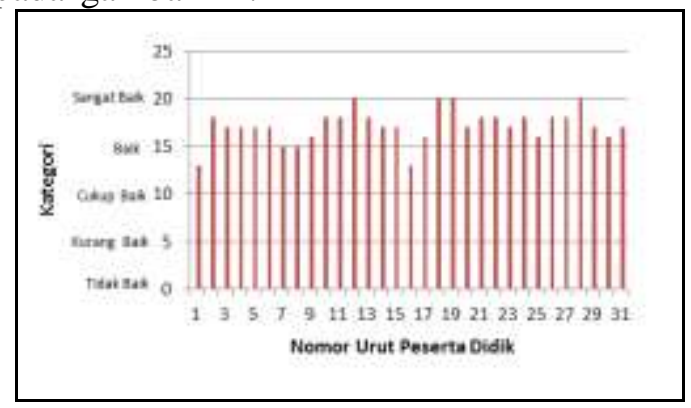

Gambar 12. Diagram Hasil Pengamatan Karakter Kreatif Kelas Eksperimen pada Uji Coba Lapangan

Berdasarkan gambar 12 dapat dideskripsi hasil pengamatan peserta didik KE pada masing-masing karakter siswa ke dalam bentuk diagram persentase seperti yang tersaji pada gambar 13. 


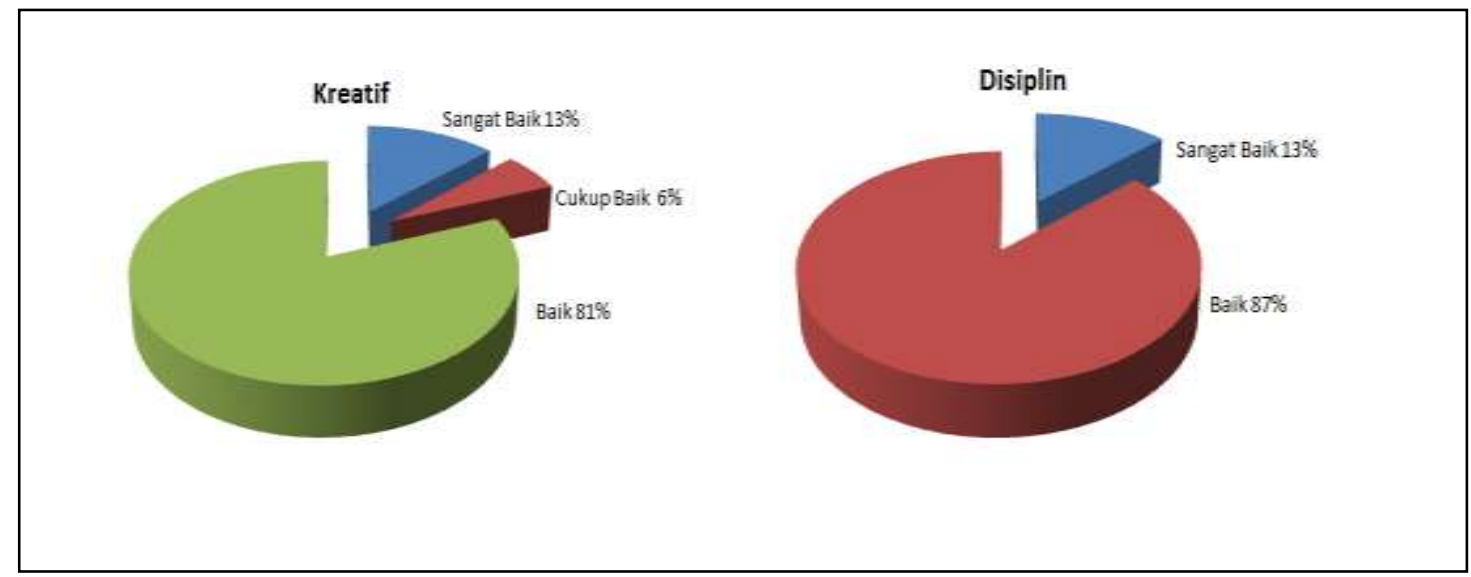

Gambar 13. Diagram Ketercapaian Karakter Siswa Kelas Eksperimen pada Uji Coba Lapangan

Gambar 13 menunjukan bahwa jumlah persentase siswa KE yang berkategori "baik" pada karakter disiplin sebesar $87 \%$ dan berkategori "sangat baik" sebesar $13 \%$. Sehingga total siswa yang berkategori sama atau diatas "baik" ada 100\%. Pada karakter kreatif jumlah persentase siswa yang berkategori "cukup baik" sebesar $8 \%$, berkategori baik $81 \%$ dan $13 \%$ lainnya berkarakter "sangat baik". Sehingga jumlah persentase siswa yang berketegori diatas "baik" ada 94\%.

Berdasarkan gambar 12 dan gambar 13 dapat diketahui bahwa baik di KK maupun di KE persentase siswa yang berkategori sama atau di atas "baik" pada karakter disiplin adalah sebesar $100 \%$. Akan tetapi apabila dianalisa rerata total skor aktual KK dan KE pada masing-masing karakter akan terlihat perbedaan. Terdapat peningkatan rerata skor pada KE dibandingkan KK pada kedua jenis karakter yang dikembangkan. Perbedaan peningkatan rerata skor tersebut dapat dilihat pada tabel 11, sedangkan hasil dalam bentuk diagram dapat dilihat pada gambar 14 .

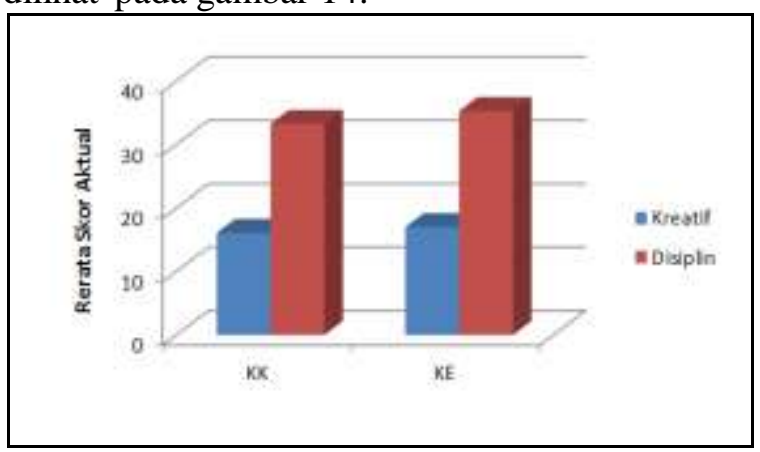

Gambar 14. Diagram Rerata Ketercapaian

Karakter Siswa Kelas Kontrol dengan Kelas Eksperimen pada Uji Coba Lapangan

Berdasarkan Gambar 14 rerata total skor aktual karakter pesertadidik KE lebih tinggi dibanding KK. Rerata total skor aktual karakter disiplin dan kreatif pada KK masingmasing adalah 33,3 dan 16,1 sedangkan pada KE rerata total skor aktual karakter disiplin dan kreatif berturut-turut adalah 35,3 dan 17,0. Kenaikan masing-masing 2,0 dan 0,9 ini mengindikasikan bahwa pelaksanaan pembelajaran dengan SSP yang mengembangkan karakter mempunyai pengaruh dalam peningkatan karakter disiplin dan kreatif. Rerata total skor aktual karakter disiplin dan kreatif pada KE masing- masing sebesar 35,0 dan 17,0 berada pada kategori "baik". Hal ini menunjukkan bahwa SSP yang digunakan dalam pembelajaran juga terbukti efektif digunakan untuk mengembangkan karakter disiplin dan kreatif.

Komponen terakhir yang digunakan dalam mengukur tingkat efektifitas SSP adalah hasil penilaian karakter peserta didik. Data hasil penilaian karakter siswa dikonversikan menjadi data skala lima. Hasil analisis data yang penilaian karakter peserta didik KK dan KE dapat dilihat pada gambar 15 dan gambar 16.

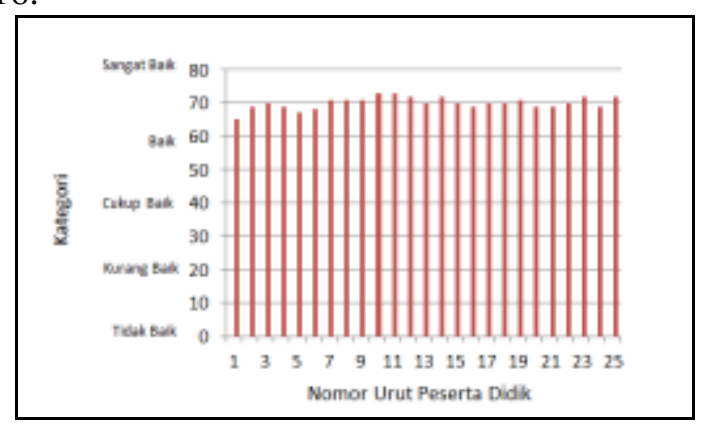

Gambar 15. Diagram Hasil Penilaian Karakter Peserta Didik Kelas Kontrol pada Uji Coba Lapangan

Gambar 15 menunjukkan bahwa seluruh peserta didik sebanyak 25 orang berada pada kategori baik atau sangat baik. Semantara pada 
gambar 16 pada Kelas Eksperimen sebanyak 31 peserta didik juga berada pada kategori baik atau sama baik.

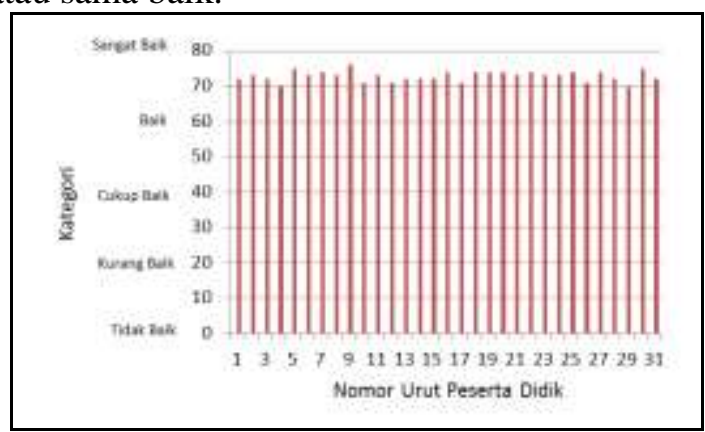

Gambar 16. Diagram Hasil Penilaian Karakter Siswa Kelas Eksperimen pada Uji Coba Lapangan

Berdasarkan gambar 15 dan gambar 16 selanjutnya dapat dideskripsi hasil penilaian karakter siswa KK dan KE dalam bentuk diagram persentase seperti yang tersaji pada gambar 17 dan gambar 18.

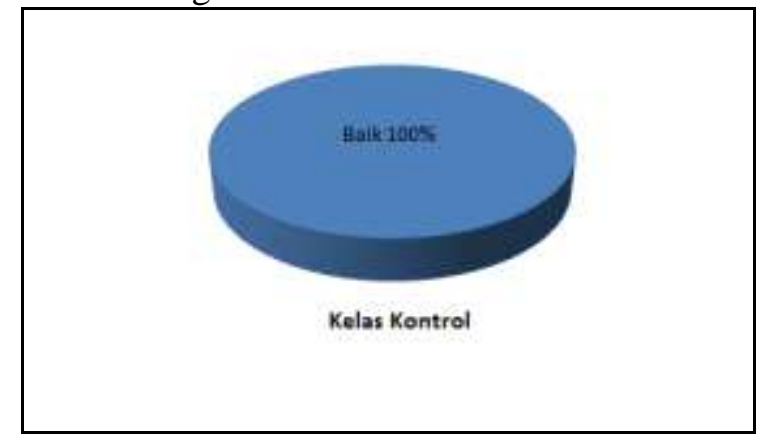

Gambar 17. Diagram Persentase Hasil Penilaian Karakter Siswa Kelas Kontrol pada Uji Coba Lapangan

Gambar 17 menunjukkan bahwa persentase siswa KK dalam penilaian karakter berkategori "baik" sebesar $100 \%$.

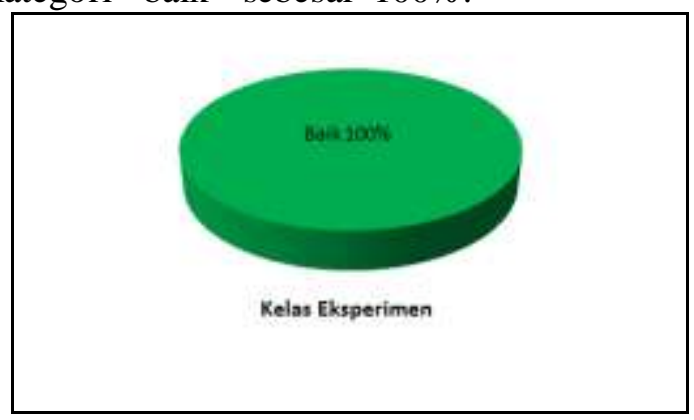

Gambar 18. Diagram Persentase Hasil Penilaian Karakter Siswa Kelas Eksperimen pada Uji Coba Lapangan

Gambar 18 menunjukkan persentase siswa KK dalam penilaian karakter juga berkategori "baik" sebesar 100\%. gambar 18 dan 19 menunjukkan persentase masing-masing sebe- sar 100\%. Perbedaan akan terlihat pada analisis rerata total skor aktual. Rerata Total skor aktual hasil penilaian karakter siswa KK dan KE pada uji coba lapangan dapat dilihat pada tabel 8 dan pada gambar 19.

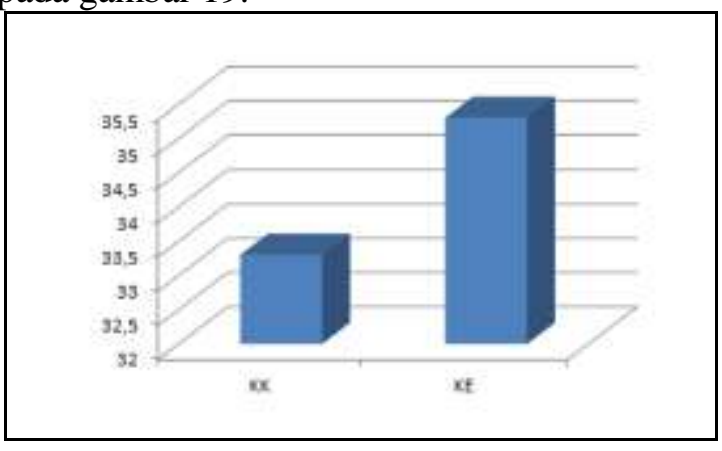

Gambar 19. Diagram Perbandingan Rerata Hasil Penilaian Karakter Siswa pada Uji Coba Lapangan

Pada gambar 19 dapat diketahui rerata total skor aktual siswa KE lebih tinggi dibandingkan siswa KK. Hasil analisis rerata total skor aktual ini mengindikasikan bahwa SSP yang digunakan dalam pembelajaran terbukti efektif dalam mengembangkan karakter siswa karena hasil analisis berada pada rentang skor berkategori "baik". Hasil analisis ini pula memberikan penjelasan bahwa SSP yang digunakan dalam pembelajaran berpengaruh positif terhadap persepsi siswa terhadap nilai-nilai karakter. Sebagai kesimpulannya, SSP yang digunakan terbukti efektif dan berpengaruh pada komponen penilaian karakter peserta didik dalam mengembangkan karakter siswa.

Berdasarkan hasil analisis yang telah dilakukan menunjukkan bahwa hasil penilaian terhadap hasil belajar (pretest-posttest), pengamatan karakter, dan penilaian karakter siswa dapat disimpulkan bahwa SSP yang dikembangkan dan diujikan pada uji coba lapangan terbukti efektif digunakan untuk mengembangkan karakter siswa.

Hasil analisis juga mengindikasikan bahwa dengan pembelajaran dengan menggunakan SSP tematik dapat mengembangkan karakter peserta didik. Dengan demikian SSP yang mengintegrasikan pengembangan karakter terbukti valid, praktis, dan efektif serta layak digunakan untuk mengembangkan disiplin dan kreatif pada siswa kelas I SD.

\section{Simpulan dan Saran}

\section{Simpulan}

Dari pengembangan mulai dari observasi awal sampai pada pelaksanaan penelitian yang 
dilaksanakan pada kelas eksperimen dengan menggunakan Subject-Specific Pedagogy (SSP) yang dikembangkan, dapat diketahui bahwa dari hasil validasi dari dosen ahli, SSP dapat dikategorikan layak untuk dilaksanakan pada saat uji coba terbatas dan uji coba diperluas dengan skor untuk silabus 47, RPP mendapat skor 65 , bahan ajar mendapat skor 65, LKPD mendapat skor 47 dan lembar penilaian dinilai valid. Jika dikategorikan maka silabus, RPP, dan bahan ajar termasuk kategori baik. Sedangkan LKPD dan lembar penilaian berkategori sangat baik.

Pembelajaran dengan menggunakan SSP terbukti efektif dalam mengembangkan karakter siswa kelas I SD ditinjau dari tes hasil belajar yang menunjukkan peningkatan nilai dan siswa yang tuntas mencapai lebih dari $85 \%$, selain itu pengamatan terhadap karakter siswa menunjukkan peningkatan pada karakter disiplin: (1) Siswa disiplin hadir di sekolah tidak terlambat (2) siswa masuk kelas dengan antri, (3) Siswa disiplin berdoa dengan duduk yang tenang, (4) siswa displin menyiapkan peralatan sekolah dengan rapi, (5) siswa disiplin mengerjakan tugas tepat waktu, (6) siswa mengumpulkan tugas dengan tertib, (7) siswa disiplin membuang sampah pada tempatnya, (8) siswa disiplin pulang dengan tidak menimbulkan suara gaduh. Pada karakter kreatif: (1) Siswa memiliki ketertarikan pada hal-hal baru, (2) siswa mampu membuat karya berbeda dengan temannya, (3) siswa dapat melakukan sesuatu dengan cara yang bebrbeda, (4) siswa dapat merancang sesuatu dengan baik. SSP yang dikembangkan dalam penelitian ini terbukti praktis digunakan oleh guru yang ditinjau dari komponen penilaian guru yang berada pada kategori "sangat baik" dan respon peserta didik yang berkategori "baik" sehingga layak digunakan dalam pembelajaran di SD.

Saran

Pengembangan SSP tematik dalam mengembangkan karakter siswa kelas I SD sudah diuji kevalidan, kepraktisan, dan keefektifannya, maka disarankan kepada guru untuk menggunakan perangkat ini sebagai alternatif pedoman dalam pelaksanaan pembelajaran yang dapat mengembangkan karakter siswa.

\section{Daftar Pustaka}

Borg, W.R., Gall M.D. \& Gall. J.P. (1983). Educational Research: an Introduction. $\left(7^{\text {th }} E d\right)$. New York: Pearson Education. Inc.

Johnson, B. (2010). Creating character education in schools. Diakses pada tanggal 29 Mei 2012, dari http://articles.everyquery.com/articles-creating-charactereducation-in schools-49579.html

Shaffer \& Kipp. (2010). Developmental psychology and adolesence, eighth edition. Belmont: Wadsworth, Cengage Learning.

Sukardjo. (2006). Kumpulan materi evaluasi pembelajaran. Yogyakarta: Universitas Negeri Yogyakarta.

Sukayati. (2004). Pembelajaran tematik di SD merupakan terapan dari pembelajaran terpadu. Makalah disampaikan pada Diklat Instruktur/Pengembang Matematika SD Jenjang Lanjut, di PPG Matemtaika. 